\title{
Is migration an effective adaptation to climate-related agricultural distress in sub-Saharan Africa?
}

\author{
Kira Vinke ${ }^{1,5}$ D . Sophia Rottmann ${ }^{1} \cdot$ Christoph Gornott $^{1,4} \cdot$ Pascal Zabre $^{2}$. \\ Patricia Nayna Schwerdtle ${ }^{3} \cdot$ Rainer Sauerborn $^{3}$
}

Accepted: 22 September 2021/ Published online: 27 October 2021 / Published online: 27 October 2021

(c) The Author(s) 2021

\begin{abstract}
Migration is often considered a form of climate change adaptation by which individuals, households, and communities seek to reduce the risks associated with climate change. In this study, we examine first-time seasonal migration out of a village in North-Western Burkina Faso to neighbouring countries, triggered by more irregular rainfall patterns. Through a set of 52 qualitative interviews, we analyse the perceptions of migrants themselves as well as the sending community regarding migration consequences. Men migrated in the off-season, whereas women stayed behind. Most migrant men and wives of migrants perceive migration to have negative consequences for their socio-economic situation and their health. Despite this, a lack of options and deteriorating environmental conditions might force the men to move again. We interpreted the range of narratives provided by women and men against the background of the scientific literature on migration as climate change adaptation. While migration could be beneficial, this study challenges the notion of migration as an effective adaptation strategy for people in climate-vulnerable settings, who lack other options.
\end{abstract}

Keywords Migration $\cdot$ Climate change $\cdot$ Health $\cdot$ Gender $\cdot$ Food security $\cdot$ Burkina Faso $\cdot$ Sahel

Kira Vinke

vinke@pik-potsdam.de

1 Potsdam Institute for Climate Impact Research, Potsdam, Germany

2 Centre de Recherche en Santé de Nouna, Nouna, Burkina Faso

3 Heidelberg University Institute of Global Health, Heidelberg, Germany

4 Agroecosystem Analysis and Modelling, Faculty of Organic Agricultural Sciences, University of Kassel, Kassel, Germany

5 German Council on Foreign Relations, Berlin, Germany 


\section{Background}

Migration has frequently been described as a form of climate change adaptation (Black et al., 2011a, b; Gemenne \& Blocher, 2017; Kniveton et al., 2012). Yet, accounts of migration in the context of climate change tend to fall on a continuum from migration as a successful form of adaptation, to migration as a failed strategy. In this study, we explore the perceptions of seasonal migration events in Bourasso, Burkina Faso from two angles: (i) men migrating away from the study village and (ii) wives of migrants (and key informants) in the sending community staying behind.

This research provides qualitative evidence demonstrating that in Bourasso climaterelated seasonal migration by migrant men was predominately perceived as an erosive or failed strategy. By reflecting on the different gendered experiences that emerged from interviews with migrant men and the wives of migrants, this paper contributes also to the discourse on gender-related climate migration. Our research thus builds on two main subsets of the climate change and migration literature. Firstly, climate-related migration as adaptation in Sub-Saharan Africa (SSA), a part of which examines migration as a means of livelihood diversification and insurance against risk. This relates to the Warner et al. (2012) and Warner and Afifi (2014) framework for conceptualizing migration effectiveness, which we use to contextualize our findings. Second is the gendered nature of climate-related migration, which is a less developed area of research.

\section{Migration as climate change adaptation}

An established body of literature on climate-related migration as a form of adaptation to climate change in SSA has developed over almost three decades. Shifts in weather patterns and increasing extreme events due to climate change will affect rural outmigration, especially in areas reliant on rain-fed subsistence agriculture (FAO, 2019; Porter et al., 2014). Under climate change, SSA experiences increasing variability of both rainfall and temperature which are detrimental to crop plant growth. Households employ a range of risk reduction strategies, including migration (Jaeger et al., 2010).

We use a prominent analytic framework for conceptualizing migration effectiveness which seeks to explain how households use migration to manage risk in the context of rainfall variability and food insecurity (Warner et al., 2012; Warner \& Afifi, 2014). This framework delineates a migration effectiveness continuum between "migration improves livelihood in the long term" and migration as a "failed strategy." The framework sheds light on the debate about the extent to which migration is a positive adaptation strategy and addresses the circumstances under which migration may constitute an undesirable and erosive strategy (Warner et al., 2012; Warner \& Afifi, 2014).

There is consensus in the climate change research community that human migration behaviour is influenced by risk exposure, vulnerability, and adaptive capacity (McLeman \& Smit, 2006; Field et al., 2014). Various studies depict several strategies that rural populations in SSA use to adapt to recurring droughts, including migration (McLeman \& Smit, 2006). For example, during times of drought and after adopting other coping measures such as selling assets and reducing food intake, Ethiopian families in dryland areas opted to migrate (Meze-Hausken, 2000). In the 1980s in northern Ethiopia, migration was used to adapt to large-scale famines 
(Ezra, 2001). The drivers, patterns, and outcomes of climate-related migration are deeply heterogeneous, with universal patterns unlikely to emerge. A few examples to illustrate this heterogeneity; In Burkina Faso, Henry et al. (2004) showed that land degradation and ongoing environmental change exerted a greater influence on migration decisions than climate-related events. Conversely, in Uganda, Call and Gray (2020) reported that the primary contributor to environmental migration were climate anomalies, in particular heat stress, rather than land degradation. In this case, temporary migration increased due to short hot spells and constituted a diversified livelihood strategy. Longer-term heat stress-induced permanent migration (Call \& Gray, 2020).

Notwithstanding the variable pressures exerted by migration drivers and the diverse mobility responses that follow, the degree of choice regarding the migration decision also varies in different populations and contexts. Migration is considered a core element of household adaptation and survival and less so a choice, especially in areas reliant on rain-fed subsistence agriculture (Weinreb et al., 2020). This is supported by research evaluating the effect of changing weather patterns on migration across 41 sub-Saharan African countries over 35 years, leading to the recommendation to sustainably transform rural structures to enable people to stay in place (Weinreb et al., 2020). Supporting this view of migration as adaptation, three historical case studies of famines and migrations in rural northwest Nigeria highlighted the possibility that both heavy, poorly timed rainfalls and severe droughts might contribute to famines and large-scale migrations from the Sahel to the Savanna, which has served a historical function as a refuge for food-stressed populations. Economic (labour) migration and family migration to the Savanna enabled people to preserve rights to farmland in the Sahel (Grolle, 2015). Other research in Niger suggests that local adaptation and labour migration have been losing their effectiveness (Olivier de Sardan, 2007). Hence, it becomes uncommon for households to be self-sufficient with staple foods thus worsening seasonal hunger episodes. Village-level strategies that had previously only been used during famines became incorporated into everyday livelihood systems, such as selling firewood and wild food plants. Further, remittances sent from migrating men became increasingly important (Grolle, 2015).

In recent decades, migration patterns have become increasingly seasonal and transnational due to natural resource scarcity as well as climate stressors (Kniveton et al., 2012). Some studies are concerned with understanding to which extent migration features as one adaptation strategy amongst other alternatives (Brown \& Crawford, 2008; Barbier et al., 2009; Traoré \& Owiyo, 2013). For example in Burkina Faso, pastoralists (mainly men) opted to migrate from the very arid north to the southern part of the country, for higher rainfall and more fertile land. Others migrated to the Ivory Coast where many worked on cocoa plantations (Barbier et al., 2009). Similarly, Brown and Crawford (2008) found that longer dry seasons in northern and central Burkina Faso prompted farmers to migrate towards more fertile lands in the east and west of the country. Confirming migration as adaptive, other studies contend that at the same time it is one of a host of livelihood adaptation options. In a review of 30 empirical studies in SSA examining mobility responses in the context of various environmental stresses, migration is conceptualized as a dynamic phenomenon responsive to the changing 
economic, social, historical, and demographic context, and with various transient and longer-term impacts (Morrissey, 2014).

Changes in livelihoods resulting from climate and environmental stress could generate novel forms of mobility that have not occurred previously, such as the first time out-migration examined in our study. Beyond asking whether migration is a form of adaptation or a failure to adapt, we ask migrants themselves, to what extent migration was adaptive in their view, for whom, and in which ways. Given we interviewed migrating men and their wives left behind in the sending community, the literature on the gendered impacts of climate-related migration is also relevant.

\section{The gendered nature of migration}

A closely related body of evidence that provides additional insights into the questions raised about the adaptive potential of climate-related migration is the gendered impacts of migration. Though understudied, gender influences the mobility responses that individuals, households, and communities opt for in the context of climate change. The overall drivers of migration differ for women and men and climate change may shape the consequences of migration differently for men and women, boys, and girls (Hunter \& David, 2009).

Household deliberations on migration are gendered because they reflect social roles including women's reproductive and domestic roles and men's general superior social position in societies across SSA (Caldwell et al., 1992; Kandiyoti, 1988). Historically, women in developing countries have been more constrained than men in migration decisions (Donato et al., 2006; Curran \& Rivero-Fuentes, 2003; Massey et al., 2010). Notwithstanding constraints, some authors consider the incentive to migrate to be higher for women than men, due to women's limited access to land or other capital (Carr, 2005; Gray, 2010). Over recent decades, some studies have documented a "feminization of international migration" (Curran \& Rivero-Fuentes, 2003; Donato et al., 2006).

Concerning internal migration, age patterns vary by gender with many adolescent women moving to urban areas to work domestically (as maids), while older women often return to origin (Menashe-Oren \& Stecklov, 2017). In Western Sudan, male household members regularly migrated to Khartoum in search of wage labour when times of low rainfall hindered agricultural production (Afolayan \& Adelekan, 1999). In rural Burkina Faso, the likelihood of inter-village migration was three times higher for men living in the poorest agro-climatic regions (rainfall 200-499 mm), compared to those living in regions with an average rainfall of $900 \mathrm{~mm}$ (Henry et al., 2004).

While SSA has seen a significant increase in the education of women and girls in the past few decades, there is concern that climate-related pressures threaten the extraction of girls from school as families send young women to cities to work domestically (Morokvasic, 1984; Cattaneo \& Robinson, 2018). This may result in increased rural out-migration of younger women. Alternatively, this trend may incentivize support for women to move to settings with the promise of a better quality of life, possibly increasing income stability within the extended family, due to 
remittances. Recent evidence suggests that girls in SSA are delaying the transition from school into the labour market relative to boys (Doss et al., 2020), which may lead to an older age profile amongst rural women out-migrants in areas with higher climate variability (Weinreb et al., 2020).

Different social groups, such as men and women or migrants and non-migrants, have distinct perceptions of the benefits and costs of migration (Jacobson et al., 2019). In summary, in the cumulating climate migration literature, human mobility is seen as an impact of climate change. The discourse shifted to view migration as an adaptation strategy, potentially enabling income diversification (Greiner et al., 2015; Raleigh et al., 2008; Sakdapolrak et al., 2016). When evaluating migration as adaptation, both economic factors, such as remittances or income level after migration, as well as non-economic factors, such as health and wellbeing, need to be assessed. The literature on climate change, migration, and health nexus is still weak, as Schwerdtle et al. $(2018,2020)$ analysed. Natarajan et al. (2019) point out that structural limitations, such as economic and social precarity, can hinder the effectiveness of migration as an adaptation to climate change.

Against the background of the available literature, we investigate the research question: was migration perceived to be an effective adaptation strategy, by whom, and what did it achieve? By investigating whether migration was a successful adaptation to climate change and through adding nuance on gender-related migration outcomes, we advance the research field of adaptation and migration studies. We compare the outcomes of our qualitative interview analysis to the analytical framework by Warner et al. (2012) and Warner and Afifi (2014) that profiles adaptive capacity and erosiveness of migration in the context of climate change.

\section{Theoretical approaches}

The New Economics of Labour Migration (NELM) considers not only individuals, but households to determine migration decisions (Stark \& Bloom, 1985). While there can be power imbalances between men and women, women are generally consulted by men before they migrate. However, cultural and family-specific contexts play a significant role. The NELM suggests that smallholder farmers are more likely to make changes in their farming methods or invest in technologies when they have the financial means to do so (Konseiga, 2007). In the absence of financial resources and food, smallholder farmers are forced to seek alternative sources of income. The accounts given by migrants and sending communities in Bourasso indicate that migrating households lacked food in their homes because of poor harvests. At the same time, the majority of households did not have financial resources to adapt their farming practices in place or invest in other farming technologies, which had the potential to improve harvests. Middlemen came to the village and offered these families work opportunities abroad. These concurrent circumstances form our understanding of migration in Bourasso as an attempt to adapt to the dire effects of climate change.

Warner and Afifi (2014) suggest avoiding the question as to whether climate change is the sole cause of migration, but rather examining the role of migration 
in managing climate-related risks. The authors developed a framework that evaluates various socio-economic factors taking place during and after migration to assess how successful migration was in adapting to changing environmental conditions. Specifically, they look at the indicators: economy, adaptation options, education, migrant characteristics, and remittances. This framework is highly relevant to the case of Bourasso, as it allows a structured categorization and appraisal of the qualitative interviews to determine the effectiveness of seasonal migration on a case to case basis. While Warner and Afifi's categories are largely applicable to our respondents' situation, we chose to extend the framework to capture all indicators that emerged as particularly relevant in Bourasso. The following indicators emerged as most important for Bourasso: households' economic situation, food security, health, wellbeing, and whether to migrate again. Building on the NELM and the Warner and Afifi framework, this study looks at migration as a household adaptation strategy, which was shaped by climate-related crop yield decline and the lack of alternative income sources (Stark \& Bloom, 1985; Warner \& Afifi, 2014; Weinreb et al., 2020). Through this lens, we investigate the migration outcomes in Bourasso.

\section{Setting and research design}

Burkina Faso is populated by 19 million people, and its population is growing at a rate of $3.1 \%$ per year. The country is landlocked and its economy depends heavily on rain-fed agriculture, mainly staple crop production, as well as cattle-raising (Doso Jr., 2014). Approximately $85 \%$ of the labour force is engaged in agriculture, which is dominantly rain-fed subsistence production. Agricultural inputs, such as irrigation, fertilizer, or pesticides, are hardly used and therefore harvests are particularly dependent on weather conditions (Henry et al., 2004; UNPEI, 2018; Kniveton et al., 2012; Somé \& Jones, 2018; Tankari, 2020).

Weather conditions are increasingly influenced by climate change. This is especially true for rainfall and temperature, which are showing more severe, longer, and more frequent extremes (IPCC, 2021). Burkina Faso's rainy season is from June through to September, with the rest of the year being largely dry. Long-term analysis of rainfall in Burkina Faso (1950-2013) shows a decrease in annual precipitation (Pearson, 2018). Dry spells and heatwaves at sensitive times within crop development are especially detrimental to rain-fed agriculture, overall causing low or failed harvests (Mank et al., 2021).

Burkina Faso's population is historically mobile, as is the case for many Sahelian countries. Since 2019, intercommunal tensions have escalated into violent conflicts through Islamic terrorism spilling over from Mali. This has caused large-scale displacements within Burkina Faso. In 2020, over 800,000 Burkinabé were internally displaced (UN OCHA, 2020). Before the violence erupted, growing climate change pressures increased food insecurity in parts of the country (Belesova et al., 2017, 2018, 2019) potentially increasing internal mobility in a setting where seasonal migration is widespread.

The case of our study village, Bourasso (Fig. 1) is special and puzzling on two accounts: (1) the soil in Bourasso is fertile and includes several low-lying fields 


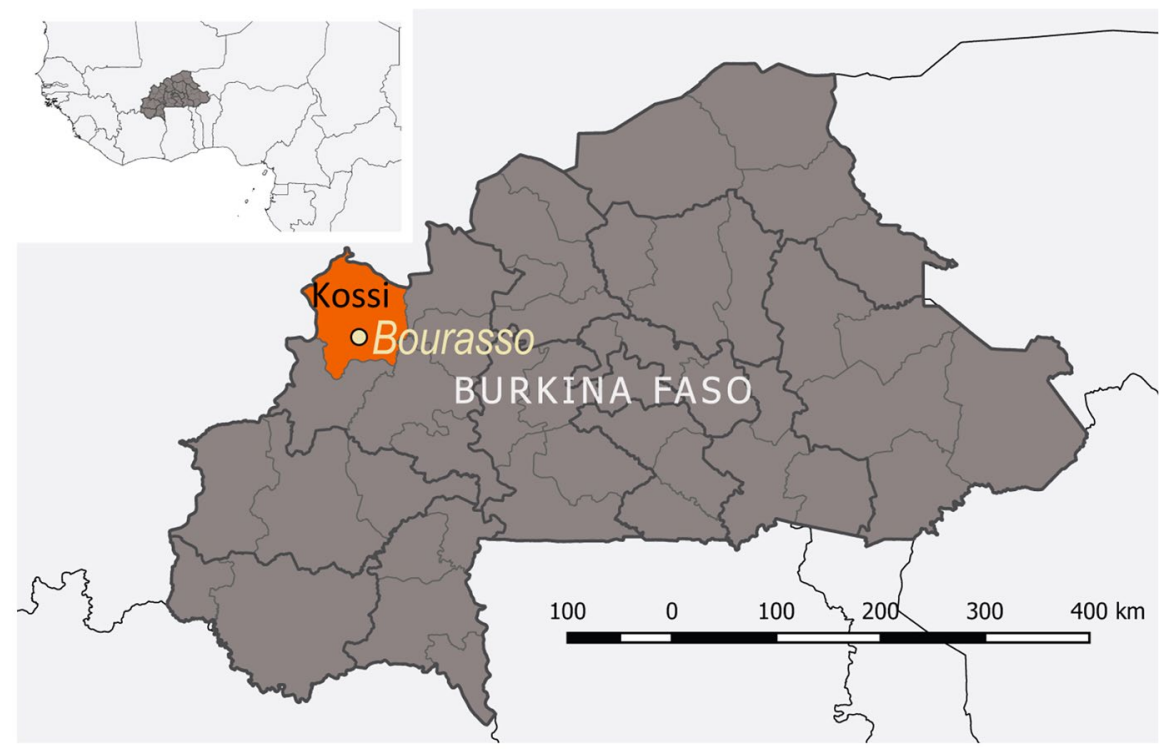

Fig. 1 Geographical location of the study village Bourasso

("bas-fonds"), where surface water is retained long into the dry season. Bourasso has had food crop excesses for most of the past 20 years, allowing people to sell grains and use millet and sorghum to brew beer. This autochthonous village of approximately 3500 inhabitants was founded at least 200 years ago and comprises mostly farmers of the Bwaba ethnic group (87\% of the population). In the area, Bwabas are known to be excellent farmers. Livestock plays a minor role in their livelihoods. (2) For the first time in living memory, a large number $(>50)$ of male subsistence farmers migrated out of this village to work on industrial plantations in neighbouring countries. This took place between November 2016 and February 2017 and lasted for 3.8 months on average.

\section{Methods}

As migration was a new phenomenon in this village, potential interview partners were sampled based on a list provided by the village head, who identified migrating households. The field research was approved by the Nouna Ethical Committee and informed consent was obtained before each interview. To assess the effectiveness of migration as an adaptation strategy, we analysed the experience of seasonal migration from two perspectives. Namely, the individual migrant himself, as well as the sending community, represented by the wives of migrants. Key informants from the sending community were interviewed to receive background information and to triangulate results. They were people with specific expertise of relevance to this study, for example, village leaders and agricultural specialists from the province. We thus applied a multi-level perspective to assess the value of migration as an adaptation 
strategy by involving both the migrating individual as well as the sending community (Gemenne \& Blocher, 2017). Moreover, the three sources of information captured in this study allow for triangulation of our findings, which in turn strengthens the validity of the results.

Two sets of interview guides were developed, one directed at migrants themselves and one directed at the sending community. They addressed three areas of interest: (i) demographic information, (ii) the reasons for migration and migration history, and (iii) the living situation and challenges before and after the migration. When appropriate, probing questions were used for clarifications or more detailed analysis. We reached theoretical saturation (Saunders et al., 2018), as themes and types of experiences recurred. Interviews were carried out individually, reducing the risk that either spouse was influenced by the presence of their partner throughout the interview or vice versa.

A total of 52 semi-structured qualitative interviews were carried out in Bourasso, each lasting about $40 \mathrm{~min}$. Thirty migrant men, 18 wives of migrants, and four key informants were interviewed (see 22). In Table 1, we provide an overview of the population of migrant men we interviewed and summarize their migration experience.

The average age of interviewed migrant men was 31 years. Most migrated to Ivory Coast (20) and fewer to Mali (9). The majority worked on plantations and gold mines. The average age of interviewed women was 28 years. Eight women named their main occupation as farming, seven housekeeping, and three beer brewing. The average age of key informants was 47 years. All interviews were recorded after informed consent was given. We transcribed and translated the interviews from the local languages Dioula and Bwamu into French and finally into English. To ensure the veracity of the translation, the research partner Centre de Recherche en Sante de Nouna administered and oversaw the translations.

Our qualitative interview analysis is based on a grounded theory approach building hypotheses based on the interview responses and utilising coding and categorization as tools of interpretation and analysis (Strauss \& Corbin, 1967). The inclusion of different gender perspectives has only recently emerged in migration studies (Pisarevskaya et al., 2019). As the different gendered experiences become salient throughout the interviews, we discuss gender as a secondary theme throughout our analysis. We begin the analysis by reviewing the expressed reasons for men's migration (O'Reilly, 2016), before turning to each group's perceptions of the migration experience. Our understanding of the situation before the seasonal migration was based on each group's narration after the return of migrants. We intentionally refer to our findings as "perceptions", as the results from the interviews are based on individual, subjective experiences of migration.

We classify the perceived outcomes following migration from the perspective of migrants and their families in Bourasso along a continuum spanning "migration as an effective strategy" and "migration as a failed strategy", a framework that builds upon Warner and Afifi (2014) (see Fig. 2). We considered migration by and large as effective, if the interview analyses fell in either of the two categories: "improvement of livelihoods in the long term" and "survive, but not flourish". We considered migration as ineffective when respondents gave answers indicating that the 


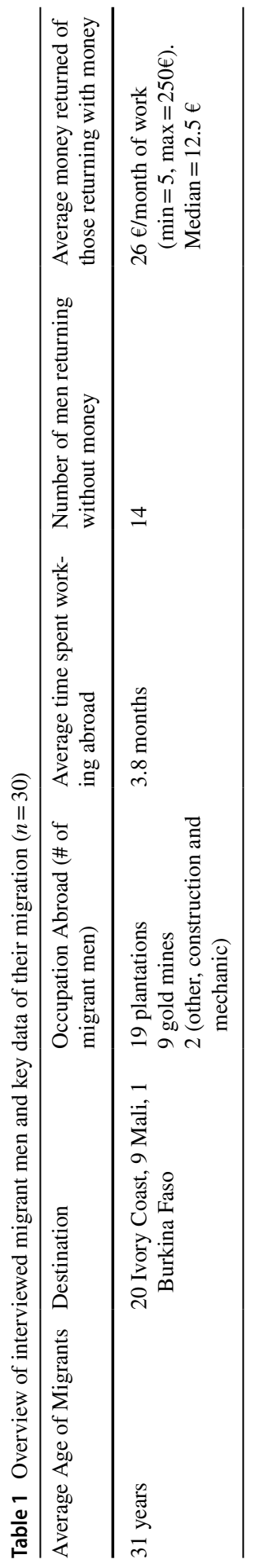


migration was either an "erosive coping" or "failed strategy". The different themes used to determine effectiveness are economic situation, food security, health, wellbeing, and the desire to migrate again (see Fig. 2).

\section{Results}

In the following section, we present the results of the interview analysis in two steps. First, we present outcomes of migration as perceived by migrants and the wives of migrants. Second, we present the categorization of migration effectiveness. The analysis was grounded in the coding and categorization through which several major themes evolved throughout the research that is reflected below.

The interview analysis highlights the close relationship between low rainfall, poor harvests, and food insecurity on the one hand, and the need to earn money and improve one's livelihood on the other hand. There was high consistency amongst respondents in drawing a clear link between needing to earn money to make up for poor harvests and feed their families, as explained in the following statement:

Respondent (R): It's misery that made us migrate.

Interviewer (I): And what else?

\begin{tabular}{|c|c|c|c|c|}
\hline 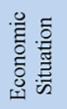 & $\begin{array}{l}\text { Income from seasonal } \\
\text { labor profitable beyond } \\
\text { compensating losses. } \\
\text { High remittances }\end{array}$ & $\begin{array}{l}\text { Income compensates } \\
\text { losses. Moderate } \\
\text { remittances }\end{array}$ & $\begin{array}{l}\text { Income does not } \\
\text { compensate losses. Low } \\
\text { remittances }\end{array}$ & $\begin{array}{l}\text { Income does not } \\
\text { compensate losses. No } \\
\text { remittances }\end{array}$ \\
\hline ठ & $\begin{array}{l}\text { Medium to long-term } \\
\text { improvement }\end{array}$ & Short- term improvement & No improvement & $\begin{array}{l}\text { Deteriotation through } \\
\text { migration }\end{array}$ \\
\hline 吾 & $\begin{array}{l}\text { Migrant's / household's } \\
\text { health is improved } \\
\text { through increased food } \\
\text { security and access to } \\
\text { health services }\end{array}$ & $\begin{array}{l}\text { Migrant's / household's } \\
\text { health remains the same / } \\
\text { slight improvements are } \\
\text { observed }\end{array}$ & $\begin{array}{l}\text { Migrant's / household's } \\
\text { health remains the same / } \\
\text { slight improvements are } \\
\text { observed }\end{array}$ & $\begin{array}{l}\text { Migrant's / household's } \\
\text { health worsened } \\
\text { significantly. Severe illness } \\
\text { during migraion/ work } \\
\text { accidents/ introduction of } \\
\text { communicable diseases / } \\
\text { STDs to communitiy }\end{array}$ \\
\hline 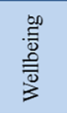 & $\begin{array}{l}\text { Positive outlook on the } \\
\text { future, no distress, } \\
\text { resolve of hardship }\end{array}$ & $\begin{array}{l}\text { Neutral outlook on the } \\
\text { future }\end{array}$ & $\begin{array}{l}\text { Negative outlook on the } \\
\text { future / tiredness / shame }\end{array}$ & $\begin{array}{l}\text { Negative outlook the } \\
\text { future / hopelessness } \\
\text { and disillusionment are } \\
\text { voiced }\end{array}$ \\
\hline \multirow[t]{2}{*}{ 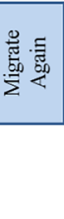 } & $\begin{array}{l}\text { Yes, migration perceived } \\
\text { as a beneficial strategy / } \\
\text { No need in the near } \\
\text { future }\end{array}$ & $\begin{array}{l}\text { Yes, migration perceived } \\
\text { as a necessary strategy / } \\
\text { No rest needed, focus on } \\
\text { village. }\end{array}$ & $\begin{array}{l}\text { Yes, out of desperation / } \\
\text { No negative effects too } \\
\text { high }\end{array}$ & $\begin{array}{l}\text { Yes, out of desperation. } \\
\text { No, unable / hardship and } \\
\text { no gain. }\end{array}$ \\
\hline & $\begin{array}{l}\text { Migration improves } \mathrm{HH} \\
\text { livelihood in long term }\end{array}$ & $\begin{array}{l}\text { Migration used to } \\
\text { survive, but not flourish }\end{array}$ & $\begin{array}{c}\text { Migration erosive coping } \\
\text { strategy }\end{array}$ & Migration failed strategy \\
\hline
\end{tabular}

Fig. 2 Migration effectiveness framework (adaptation by the authors from Warner \& Afifi, 2014; Warner et al., 2012) 
R: It's misery, it did not rain well, and the famine was so strong, and [we] needed food so badly, and then this man came to us telling us that he was looking for people to go work, so we did not hesitate a little bit to follow him and go there (Interview M29 ${ }^{1}$ ).

The latter part of the quote refers to the role of recruiters, who try to attract farmers to work on industrial plantations in neighbouring countries.

\section{Migration outcomes}

Households were confronted with existential challenges before and during migration. While both men and women experienced the migration to be ineffective, different reasons were given for this. These reasons shed light on divergent gendered experiences of migration as adaptation (Table 2). For migrant men, the main themes revolved around lack of economic gain, continued food insecurity, harsh working conditions, and health problems during migration. For the wives of migrants, themes centred on continued food insecurity, lack of money to buy food, and other necessities as well as the burden of caring for children alone. The health of children and migrant men also emerged as a key concern of wives of migrants. They were especially apprehensive of their husbands returning with sexually transmitted diseases.

\section{Migrant men: economic situation and food security}

By and large, the economic situation of the migrants and their households was not improved through migration. Migrants worked mostly in gold mines or sugar cane plantations, neither of which turned out to be profitable for them. A common theme arising in the interviews was the lack of income and subsequent lack of remittances. This in turn was often linked to fraud and theft. In many cases, the men were recruited under false pretences and were promised lucrative work. Some migrants, however, were able to bring back money and they saw the benefits for the village as a whole. One migrant who brought back the equivalent of 112 Euro after three months' work reports:

According to our analysis, when we leave the village to go work somewhere else, the little money that we will earn will be spent in the village here, so it contributes somehow to the development of the village, as a result, the movements of the young people are advantageous to the village. For example, when I came back, I did all my expenses here, and this money has been invested in the village (Interview M5).

For those who were able to generate income, the amounts were generally below their expectations and could not make up for the harvest losses. The few migrants who did bring back money returned with an average of 26 Euro per month. Forty of the men reported that they could not bring or send back any money at all.

1 "M" stands for migrant male, and "W" for wives of migrants as respondents. 


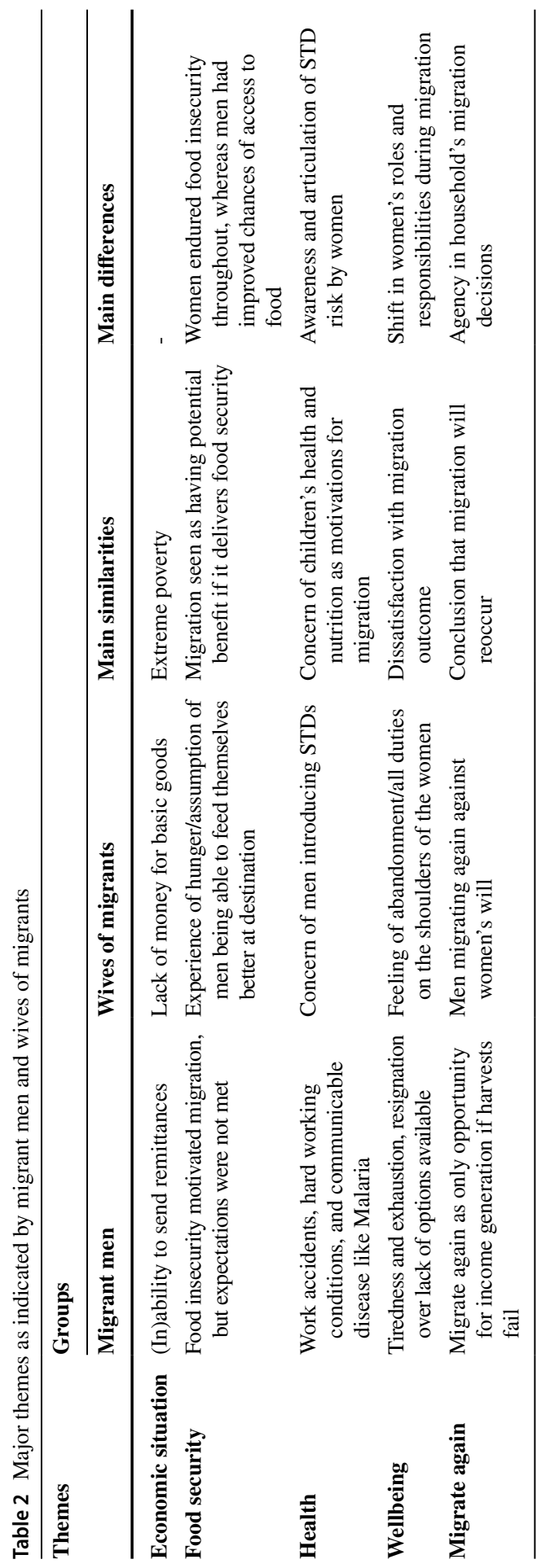


I: Did you send money to your family while you were there?

$\mathrm{R}$ : « Laughing » I was not able to send any money.

[...] We did not get any money, the way we were enthusiastic before our departure. When we got there, we found out that the work was very difficult and we could not get much money (Interview M26).

R: They told us one thousand francs for every twenty-five meters [of sugar cane], but when we arrived there, it did not happen that way. It happens that you work and then you don't even get thousand francs (€ 1.52). And it is also us, who took charge of our food (Interview M20).

Several interviewees pointed to a group ("they") or an individual "boss", who introduced them to labour migration. Some migrants suffered fraud or theft and even reported problems in paying the bus fare to return home.

R: The way back was a big problem because we worked and the boss ran away

with the money before the end of the contract (Interview M24).

This statement reflects how migrants can become trapped in their destinations, unable to return home. Some accounts reflect the men's feelings of shame over failing to provide for their families, despite exposing themselves to risks and hardship during migration.

When asked to compare migration with non-migration, most men perceived migration as detrimental:

R: The year we did not migrate and we stayed here to work, that year was better than the year I migrated. [...]

If you migrate and then the situation is still bad, this shows that here it is better than the place you migrated [to] (Interview M24).

When you are poor and have nobody to help you out, you can't do anything. You will be bound to go for a trip hoping to get something beneficial for the family, [as] we have no other sources of income here (Interview M3).

I don't have a choice, I have no external help. It's an obligation for me to migrate (Interview M30).

The quotes show that the decision for seasonal migration is the last measure of adaptation for which high non-economic costs are borne. Migration is not seen as positive, rather the quote from M3 reflects that men view migration as a duty to improve their family's situation.

\section{Migrant men: health and wellbeing}

Migrants reported being exposed to a variety of health risks throughout their migration. Sixteen of the 30 migrants reported contracting malaria. Six migrants mentioned that they accidentally cut themselves with the equipment used for harvesting sugar cane. Precarious working conditions, exploitation, and lack of basic safety measures in sugar cane plantations and gold mines in the Sahel region are welldocumented (Carayol, 2010, 2020). 
Well, and the fever, because of tiredness, often the more you work without having a rest, the muscles don't function correctly anymore, as the body can't bear it too, apart from that and the stomach-aches, and malaria, there is nothing (Interview M27).

Besides the direct physical health effects raised in the interviews, migrants also spoke of broader psychosocial consequences including exhaustion and resignation. If men did not succeed while working abroad, they would face further hardship once they returned home. The stress of this reality weighed heavily on several respondents:

It is tiring [...]. Because the things for which we left, we did not earn anything [...] in order to take care of the family. It is this kind of tiredness I am talking about that still remains. You see? The gap that we said that we are going to fill

- it could not be done! (Interview M22).

The pressure described by male migrants to migrate and to earn reflects the extreme poverty in the village. Several migrants describe the struggles that families and communities face. The absence of options translates into a lack of agency in determining the course of one's life.

As one farmer reflects:

The difficulties increase gradually, they never decrease. « Silence » (Interview M29).

\section{Wives of migrants: economic situation and food security}

Most wives of migrants stated several reasons, why migration could hypothetically be beneficial. These were mainly the prospect of husbands returning with money or food. Money was often linked to buying food, but also repairing and building of houses as well as caring for the sick:

If he leaves and he is able to earn a lot of money, we can buy some stuffs that we can put aside to ensure the food security (Interview W11).

Out of the 18 female respondents, who discussed their husband's migration, only two respondents reported that their husband earned money and that their migration was beneficial:

He brought some money and he bought some grains for us and this served us a lot to reach the next rainy season (Interview W10).

A third woman stated that her husband sent money home during his absence. Another respondent concluded that her husband's migration helped secure food supply at home upon return: 'We bought some millet' (interview wife of migrant 3). The remaining 14 respondents reported that their husband's migration was mainly counter-beneficial for reasons relating to lack of money returned, women being left to care for children, and continued food insecurity. The following statements underline the disappointment and frustration felt by most female respondents regarding their husband's migration: 
There is no advantage [...] He left me alone with the children. You see, you suffer in every side [...] As he left and he did not come back with money (Interview W4).

According to him, of course, this has been beneficial. He went to work there in order to feed himself [...] He left me behind with the children [...] If you go there, you must come back with something by all means for your family. If you don't then it is useless for you to go there (Interview W2).

Most female respondents were frustrated that their husbands did not return with money, while they were experiencing food insecurity and hunger. As indicated in the latter quote, women were burdened with caring for their children alone and finding food sources. Because men generally left because of poor harvests, there were severe food shortages.

The problem that we had was the problem of food. Because when he was leaving, there was nothing to eat (Interview W6).

R: Everyday, we eat what we earn $[\ldots]$.

I: Were there any days when you did not have food to eat?

$\mathrm{R}$ : This is too common (Interview W2).

Wives of migrants repeatedly connected food insecurity to the lack of income opportunities. Money is a major constraint, as it impedes all aspects of life:

R: I go to cultivate in the farms of people in order to earn money to buy millet. Sometimes, I take credits from people to buy food, and later I will reimburse. Sometimes, we don't earn anything so we have to sleep [with an] empty stomach.

I: Are there other things that the departure of your husband has caused?

R: We have a lot of difficulties.[...] Sometimes we even do not have a soap to wash the clothes, money to buy food, condiments, to send the millets to the mill, all these are difficult at times (Interview W16).

\section{Wives of migrants: health and wellbeing}

A key theme that emerged while speaking to wives of migrants was the health of both their children and their husbands. Some women reported that their children fell ill during their husband's absence and that they struggled to treat them or buy necessary medication:

Often, my children used to fall sick and I did not have money and at the pharmacy, they do not give the medicine for credit (Interview W11).

Several women reported their husbands having suffered minor ails such as 'coughs', 'headaches', as well as more severe problems such as 'back pains', which they associated with working in the mines.

Even if they did not come back with money, the fact that they come back in good health is a good thing (Interview W3). 


\section{A key informant explained:}

There is a worriedness, we wonder, will they not come back again, how will they come back, in good health? In bad health? (KI 1).

Several respondents suggested that some men came back with sexually transmittable diseases (STDs). While 11 women mentioned diseases in broader terms, seven respondents were very explicit in stating that they were concerned migrants would return with HIV/AIDS or other STDs. They saw this as a danger to themselves and the village at large:

There are some who came back with HIV. [...] It can kill a person, if you as a wife you stay in the village and your husband comes with such a disease, you can be contaminated and you may die from it. (Interview W1).

When he returns, he is likely to transmit these diseases to his wife and to the people of his village (Interview W9).

For many women, the fact that their husbands migrated was perceived as a burden. Half of the interviewed women made it very clear that they would not want their husbands to migrate again.

I: Do you want your husband to go back there again?

R: Ha! Of course, I don't. [...] As his migration did not bear any fruits, that's why I don't want him to go back there again.

I: So, even if he decides to go there next year, will you tell him not to?

Staying here is better?

$\mathrm{R}$ : Yes (Interview W3).

Nonetheless, in the context of poor harvests and few alternative income opportunities, several women stated that, if the situation remained unchanged, their husband would likely migrate again anyway:

If he chose himself to go back and suffer in order to earn a living for the family, I can't stand against it. I would accept if there is no food in the family (Interview W10).

If the rainy season is not good, he will go back of course [...] in case things don't go well, he will not stay here, he will migrate (Interview W5).

These statements and the expressed despair point to the complexity of the issue: men are pushed to migrate seasonally for lack of better alternatives. Women were reluctant to stop them, despite previous bad experiences.

\section{Categorization of migration effectiveness}

To conceptualise whether the seasonal migration was effective, we assessed how both the migrants and the women narrated their experiences. Focusing on whether experiences overall improved or worsened for each theme, we analysed the following different themes: (1) economic situation, (2) food security, (3) health, (4) wellbeing, and (5) 
migrate again (see rows, Fig. 2). In doing this, we were able to approximate where to place migrants as well as the wives of migrants $(n=48)$ within the migration effectiveness spectrum. We extracted the main shared experiences within each of these themes. We then placed all interviewees into different categories across the migration effectiveness spectrum: (1) migration improved livelihood in the long-term, (2) migration used to survive but not flourish, (3) migration as an erosive coping strategy, and (4) migration as a failed strategy (bottom categories, Figs. 2 and 3). As this analysis was based on shared narrated experiences, the categories are not determinate. Instead, they give a general indication of how effective seasonal migration is perceived by different people. Where exactly they are on the spectrum depends on the actual economic outcomes, associated food security as well as the health situation, i.e. if HIV or STDs were transmitted as well as on the weighing of beneficial and counter-beneficial outcomes across themes.

\section{Effective migration}

This groups the two categories to the left of Fig. 2 .

\section{Migration improved livelihood in the long term}

Based on our analysis, we found that there were no respondents who perceived their migration as an improvement of their households' livelihood. For migration to be seen as an effective adaptation strategy, it should result in an economic situation where revenue from migration was higher than the costs involved.

\section{Number of respondents along the migration effectiveness continuum $(\mathrm{n}=48)$}

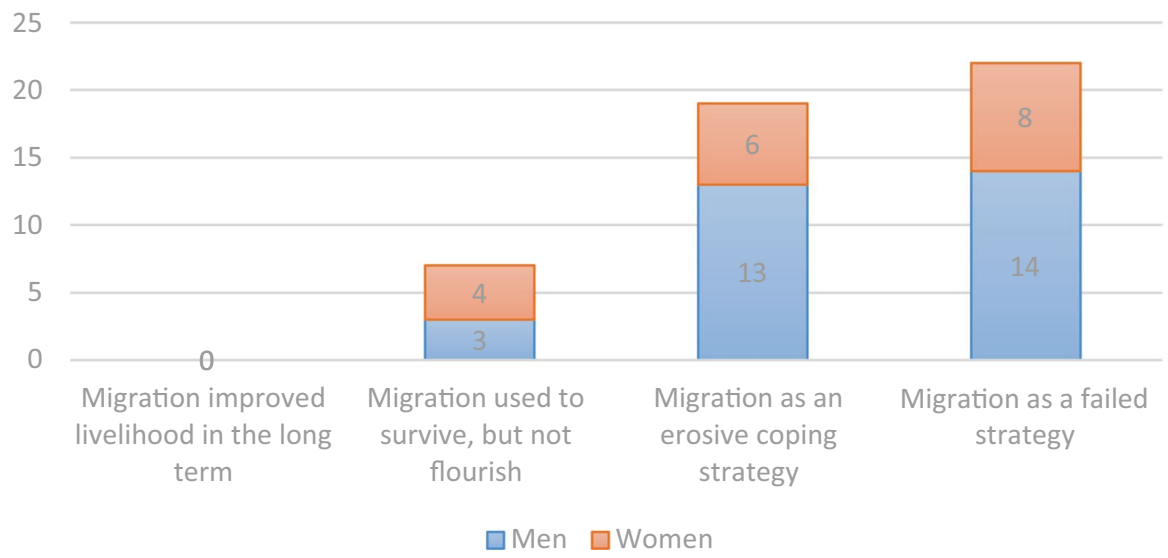

Fig. 3 Summary statistics of migration outcomes: number of respondents along the migration effectiveness continuum $(n=48)$. The categories of the migration effectiveness continuum are neither fixed nor strictly applicable to each individual case. Hence the categorization of respondents along the continuum is an approximation based on the narration of their migration experience 
Hypothetically, farm investments could improve food security in the long term. Remittances could enable access to health services. Households would either support migration in the future as it was perceived as beneficial or decline migration because it was no longer necessary. Migration would only be one option amongst several, and thereby a free choice.

\section{Migration used to survive but not flourish}

Only the responses of $15 \%$ of the study population (4 women and 3 migrant men) fall under this category. In these cases, husbands sent remittances home or returned with money or the food equivalent hereof. Moreover, migration was seen as effective in reducing food insecurity for sending households in the short term. It was in these few cases that women stated that they would support their husbands' migration again. Most women were nonetheless concerned with health issues related to migration: either their children's, their husbands', or their health in the long term (for fear that their husbands would return home with an STD). Notably, the most successful migration outcome was a man who worked as a mechanic in a hardware store, indicating that skilled migration could be more profitable.

\section{Ineffective migration}

The remaining $85 \%$ (14 female and 27 male) respondents are on the negative ( 2 categories on the right) side of the framework.

\section{Migration as an erosive strategy}

Forty percent (13 men and 6 women) of the study population fit into this category. Where remittances were low, migration was regarded as not beneficial. When migrant's health worsened during migration or the household suffered from his absence, migration was likely seen as unsustainable and hence we considered it an erosive strategy. Women on this side of the spectrum tended not to support future migration. Nonetheless, each one of them conceded that they would accept their husbands repeated migration if there were no better alternatives. Migrant men considered migrating again in case of a bad harvest because staying would mean that they were certain not to find other sources of income.

\section{Migration as a failed strategy}

Forty-six percent (14 men and 8 women) of the study population fall in this category. Where migrants failed to send remittances home and did not return with money or goods, men and women perceived migration as a failed strategy. This 
situation coincided with worsened food security, as households' purchasing power was additionally strained by potential losses from travel costs. Moreover, if the suspicions of women regarding HIV/STDs turned out to be true, their own health would be negatively affected, rendering migration a failed strategy. In such cases, women would not support migration again. Where they supported it, it was likely out of desperation and lack of alternatives.

\section{Discussion}

We set out to determine through a series of interviews with a population migrating for the first time whether migration was perceived to be an effective adaptive strategy to climate change, by whom, how, and under what circumstances. We discovered that, in this particular situation and population, migration was considered an erosive or failed strategy.

The listed themes to determine the effectiveness of migration are a further development of the work of Warner et al. (2012) and Warner and Afifi (2014) built on our research results in Bourasso. Whereas Warner and Afifi (2014) define five themes (economy, adaptation options, education, migrant characteristics, and remittances), which determine where on the spectrum of migration effectiveness the case falls, our interview data revealed that the households' economic situation, food security, health, and wellbeing and whether to migrate again or not were the strongest indicators for migration outcomes, as narrated by both the migrants and the sending communities in Bourasso (see rows in Fig. 2). Compared to the large study of Warner and Afifi (2014), our qualitative study draws out the contextual complexity and hence complements their results. The categories are neither fixed, nor strictly applicable to each case. Hence, it might be that migration introduced STDs to the household, while at the same time, the husband was able to generate reasonable income, which was then invested into farm management and can help secure food in the future. In such cases, migration might be seen as both effective with counter-beneficial features. This led us to the conclusion that migration could simultaneously build and undermine resilience in different aspects of people's lives. Labelling migration widely as a form of adaptation or as a mere impact of climate change, therefore, risks overlooking the more nuanced migration outcomes (Vinke et al., 2020).

Judging by the emerging themes, migration can be seen as generally highly ineffective in our study of Bourasso. When assessing the reasons for migration given in the interviews, our findings complement the quantitative study of De Longueville et al. (2019) that points to environmental deterioration driving short-term migration in Burkina Faso. We also saw in our case study that some populations could become trapped in the future, due to worsening conditions. We identified women as especially at risk. Black et al. (2011a, b) identified the risk for populations who are highly vulnerable to become trapped in areas that are strongly exposed to climate change impacts. Jacobson et al. (2019) found in their study in North-Western Cambodia that migration failed to provide food security and had negative effects on the sending community and in particular on women. During their husbands' absence, women were left with a higher labour burden. The authors concluded that 
complementary strategies are needed to avoid spiralling into deeper poverty through migration (Jacobson et al., 2019). In the case of Bourasso, women could become trapped in the sending areas, and migrant men were at risk of becoming trapped at their destination. Some of them did not earn enough money to pay for their return or encountered situations of debt bondage.

A lack of agency in migration decision-making, as was the case in Bourasso, is more likely to lead to negative migration outcomes (Gong et al., 2011; Hoang, 2011). While most women perceived their husbands' migration as ineffective, they conceded that they would not oppose their husbands, should they decide to migrate again in the future. This might point to a lack of agency of women in migration decision-making, a factor that has been identified to increase their vulnerability to climate change (Ayeb-Karlsson, 2020). Moreover, we could interpret this leaving the option of future migration open, as an acknowledgment of the fact that households saw this as the only option left in the face of harvest losses and the lack of alternative income opportunities. The possible benefits of remittances in poverty alleviation and the development of sending communities have been widely discussed (Gemenne \& Blocher, 2017; De Haas, 2005; World Bank, 2016). Particularly in rural subsistence economies, remittances can foster agricultural investment through knowledge or capital transfers and increase resilience through the additional income (De Haas, 2005). Repeated seasonal migration may therefore become more profitable and effective over time.

The study shows another important aspect that needs further consideration in the climate migration literature, namely the different dimensions of physical and mental health. The significance of further research on climate change, migration, and health relationships was highlighted by a systematic review paper (Schwerdtle et al., 2020). In Bourasso, women lamented that their husbands or their children got sick during the period of migration. When reference was made to husbands' ill health or sickness, it was connoted with HIV or STDs. The role of migration in contributing to the AIDS epidemic as well as the spread of STDs was widely studied across Sub-Saharan Africa in the 1990s and early 2000s. One of the findings was that people who are more mobile tend to be at higher risk for HIV and other STDs than their immobile counterparts who remain in a stable living situation (Lurie et al., 2003).

\section{Conclusion}

Our research in Burkina Faso expands the knowledge base on migration as adaptation in response to climate-related agricultural distress in SSA. We have demonstrated that migration was not an effective adaptation tool for the population we studied. A variety of factors impeded migration effectiveness, including structures of exploitation, adverse effects on health, and pressures on households who stayed behind. Had migrants been able to gain sufficient income to make up for farming losses and had negative health effects been avoided, their migration could have potentially been a successful adaptation strategy. Factors that lead to positive migration outcomes therefore deserve further attention. 
The study provided a relevant test of the Warner and Afifi framework on migration effectiveness. Our findings confirm the relative importance of the factors Warner and Afifi considered in their framework and give new insights on the gender and health dimensions of migration under agricultural distress. Women viewed migration risks and outcomes differently from men, as the potential spread of diseases played a larger role in their assessment. Gendered perspectives on climate migration are largely lacking in the existing literature and this study stresses the importance of their inclusion to better understand when migration is a successful form of adaptation. Overall, the results challenge simplistic notions of migration as adaptation and point to the diverse outcomes of migration occurring in response to climate change impacts (Sakdapolrak et al., 2016; Vinke, 2019). The findings demonstrate that through qualitative analysis, new insights about the outcome of migration as a response to climate change emerge, relating to the perceptions of migrants and their relatives, their personal experience and costs, as well as fears and expectations (Nature Climate Change, 2021).

The study carries significant implications for the region as a whole, as seasonal migration may be one of the options available to climate change-affected populations. Shifting rainfall patterns will increasingly contribute to migration pressures in impoverished areas in SSA, where people are directly reliant on functional ecosystems and more than 80 percent of the Sahel region's population is dependent on agriculture (Doso Jr., 2014). Consequently, it is indispensable to continue research on these complex interactions to shed light on the factors determining migration outcomes.

Acknowledgements We thank Dr. Moubassira Kagoné, Ole Weber, Anastasiia Polianskaia, and Frederic Grobler and the Nouna HDSS field team for their research support. We also thank the community of Bourasso for welcoming us and our research into their village.

Funding Open Access funding enabled and organized by Projekt DEAL. This work was supported by The International Climate Initiative (IKI: www.international-climate-initiative.com) and the German Federal Ministry for the Environment, Nature Conservation and Nuclear Safety (BMU) which supports the IKI on the basis of a decision adopted by the German Bundestag. We also acknowledge funding from the German Foreign Office that is supporting our work in the Sahel, the Johanna Joos Foundation, and UNHCR.

Data availability The interview data that support the findings of this study are available on request from the corresponding author K.V. The data are not publicly available due to European data protection restrictions, as they contain information that could compromise research participant privacy.

\section{Declarations}

Ethics approval Ethics approval has been obtained.

Consent to participate Informed consent was obtained from all participants.

Consent for publication Consent for publication has been obtained.

Conflict of interest The authors declare no competing interests. 
Open Access This article is licensed under a Creative Commons Attribution 4.0 International License, which permits use, sharing, adaptation, distribution and reproduction in any medium or format, as long as you give appropriate credit to the original author(s) and the source, provide a link to the Creative Commons licence, and indicate if changes were made. The images or other third party material in this article are included in the article's Creative Commons licence, unless indicated otherwise in a credit line to the material. If material is not included in the article's Creative Commons licence and your intended use is not permitted by statutory regulation or exceeds the permitted use, you will need to obtain permission directly from the copyright holder. To view a copy of this licence, visit http://creativecommons.org/ licenses/by/4.0/.

\section{Appendix}

\section{Overview of respondents}

\section{Migrant men}

\begin{tabular}{|c|c|c|c|c|c|}
\hline $\mathbf{N}^{\circ}$ & Destination & Work at destination & Amount (CFA) & Amount (EUR) & Months away \\
\hline M1 & Mali & Gold mine & 0 & 0 & 3 \\
\hline M2 & Mali & Gold mine & 0 & 0 & 5 \\
\hline M3 & Côte d'Ivoire & Sugar cane plantation & 10,000 & 15 & 3 \\
\hline M4 & Côte d'Ivoire & Sugar cane plantation & 25,000 & 37,5 & 3 \\
\hline M5 & Côte d'Ivoire & Sugar cane plantation & 75,000 & 112,5 & 3 \\
\hline M6 & Côte d'Ivoire & Sugar cane plantation & 25,000 & 37,5 & 3 \\
\hline M7 & Côte d'Ivoire & Sugar cane plantation & 0 & 0 & 1 \\
\hline M8 & Mali & Gold mine & 4000 & 6 & 7 \\
\hline M9 & Côte d'Ivoire & Sugar cane plantation & 20,000 & 30 & 3 \\
\hline M10 & Mali & Mechanic/hardware store & 500,000 & 750 & 3 \\
\hline M11 & Mali & Gold mine & 0 & 0 & 5 \\
\hline M12 & Côte d'Ivoire & Sugar cane plantation & 10,000 & 15 & 3 \\
\hline M13 & Côte d'Ivoire & Construction work & 0 & 0 & 8 \\
\hline M14 & Mali & Gold mining & 120,000 & 180 & 6 \\
\hline M15 & Côte d'Ivoire & $\begin{array}{l}\text { Other (Cocoa and palm } \\
\text { tree plantation, corn } \\
\text { farming) }\end{array}$ & 400,000 & 600 & 49 \\
\hline M16 & Côte d'Ivoire & Sugar canes plantation & 10,000 & 15 & 3 \\
\hline M17 & Côte d'Ivoire & Sugar cane plantation & 20,000 & 30 & 4 \\
\hline M18 & Côte d'Ivoire & Sugar cane plantation & 28,500 & 42,75 & 3 \\
\hline M19 & Côte d'Ivoire & Sugar cane plantation & 40,000 & 60 & 3 \\
\hline M20 & Côte d'Ivoire & Sugar cane plantation & 0 & 0 & 3 \\
\hline M21 & Mali & Gold mining & 0 & 0 & 4 \\
\hline M22 & Burkina Faso & Gold mining & 30,000 & 45 & 4 \\
\hline M23 & Côte d'Ivoire & Sugar cane plantation & 30,000 & 45 & 3 \\
\hline M24 & Mali & Gold mining & 0 & 0 & 5 \\
\hline
\end{tabular}




\begin{tabular}{llllll}
\hline $\mathbf{N}^{\circ}$ & Destination & Work at destination & Amount (CFA) & Amount (EUR) & Months away \\
\hline M25 & Côte d'Ivoire & $\begin{array}{l}\text { Other (Cocoa and palm } \\
\text { tree plantation, corn } \\
\text { farming) }\end{array}$ & 40,000 & 60 & 14 \\
M26 & Cote d'Ivoire & Sugar cane plantation & 0 & & \\
M27 & Mali & Gold mining & 0 & 0 & 3 \\
M28 & Côte d'Ivoire & Sugar cane plantation & 0 & 0 & 5 \\
M29 & Côte d'Ivoire & Sugar cane plantation & 40,000 & 0 & 3 \\
M30 & Côte d'Ivoire & Sugar cane plantation & 0 & 61 & 3 \\
\hline
\end{tabular}

${ }^{*}$ The duration of M27 and M7 does not strictly fall into our definition of seasonal migration, but they are included in this study because their intent was seasonal migration. M15 is an outlying case and not considered in the analysis

\section{Wives of migrants}

\begin{tabular}{llllll}
\hline & Age & Husband destination & Occupation & Amount (CFA) & Amount (EUR) \\
\hline W1 & N/V & Not stated & Farmer/tradeswoman & Not stated & Not stated \\
W2 & 22 & Côte d'Ivoire & Housekeeping & 0 & 0 \\
W3 & 25 & Côte d'Ivoire & Housekeeping & $\begin{array}{c}\text { Only enough to buy } \\
\text { millet and give some- }\end{array}$ & N/A \\
& & & & \multicolumn{2}{c}{ thing to village chief } \\
W4 & 34 & Côte d'Ivoire & Housekeeping & 0 & 0 \\
W5 & 30 & Mali & Housekeeping & 0 & 0 \\
W6 & 25 & Not stated & Housekeeping & 0 & 0 \\
W7 & 39 & Not stated & Farmer & 0 & 0 \\
W8 & 25 & Not stated & Farmer & Some money (no exact & N/A \\
& & & & sum) & Not stated \\
W9 & 35 & Not stated & Farmer/beer Brewer & Not stated & Not stated \\
W10 & 37 & Not stated & Farmer & Not stated & 0 \\
W11 & 22 & Mali & Farmer & 0 & 0 \\
\hline W12 & 20 & Not stated & Housekeeping & 0 & 7,5 \\
W13 & N/V & Not stated & Farmer & 5000 & Not stated \\
W14 & 22 & Not stated & Tradeswoman & Not stated & 0 \\
W15 & 26 & N/A *** She migrated & Housemaid (she also & 0 & Not stated \\
& & herself & migrated herself) & & Not stated \\
W16 & 26 & N/A & Farmer & Not stated & Not stated \\
W17 & 27 & Côte d'Ivoire & Beer brewer & Not stated & Not stated \\
W18 & N/V & Côte d'Ivoire & Beer brewer & & \\
\hline & & & & & \\
\hline
\end{tabular}




\section{Key informants}

\begin{tabular}{lll}
\hline & Age & Position \\
\hline K1 & 64 & Canton Chief \\
K2 & 38 & Chief Farmer \\
K3 & N/V & Chief Regional Agricultural Officer \\
K4 & 40 & District Agricultural Head Director \\
\hline
\end{tabular}

\section{References}

Afolayan, A. A., \& Adelekan, I. O. (1999). The role of climatic variations on migration and human health in Africa. The Environmentalist, 18(4), 213-218.

Ayeb-Karlsson, S. (2020). When the disaster strikes: Gendered (im)mobility in Bangladesh. Climate Risk Management. https://doi.org/10.1016/j.crm.2020.100237.

Barbier, B., Yacouba, H., Karambiri, H., Zoromé, M., \& Somé, B. (2009). Human vulnerability to climate variability in the Sahel: Farmers' adaptation strategies in northern Burkina Faso. Environmental Management, 43(5), 790-803.

Belesova, K., Gasparrini, A., Sié, A., Sauerborn, R., \& Wilkinson, P. (2017). Household cereal crop harvest and children's nutritional status in rural Burkina Faso. Environmental Health, 16(1), 65.

Belesova, K., Gasparrini, A., Sié, A., Sauerborn, R. \& Wilkinson P., (2018). Annual crop-yield variation, child survival, and nutrition among subsistence farmers in Burkina Faso. American Journal of Epidemiology, 187(2), 242-250.

Belesova, K., Gornott, C., Milner, J., Sié, A., Sauerborn, R., \& Wilkinson, P. (2019). Mortality impact of low annual crop yields in a subsistence farming population of Burkina Faso under the current and a $1.5^{\circ} \mathrm{C}$ warmer climate in 2100. Science of the Total Environment, 691, 538-548.

Black, R., Adger, W. N., Arnell, N. W., Dercon, S., Geddes, A., \& Thomas, D. (2011a). The effect of environmental change on human migration. Global Environmental Change, 21, 3-11.

Black, R., Bennett, S., Thomas, S. M., Reddington, J. R. (2011b). Migration as adaptation. Nature, 478, 447-449. https://doi.org/10.1038/478477a

Brown, O., \& Crawford, A. (2008). Assessing the security implications of climate change for West Africa: country case studies of Ghana and Burkina Faso. Winnipeg, Manitoba: International Institute for Sustainable Development.

Call, M., \& Gray, C. (2020). Climate anomalies, land degradation, and rural out-migration in Uganda. Population and Environment, 41, 507-528. https://doi.org/10.1007/s11111-020-00349-3

Carr, E. R. (2005). Placing the environment in migration: environment, economy, and power in Ghana's Central Region. Environment and Planning A, 37(5), 925-946.

Caldwell, J. C., Caldwell, P., \& Orubuloye, I. O. (1992). The family and sexual networking in sub-Saharan Africa: historical regional differences and present-day implications. Population Studies, 46(3), 385-410.

Carayol, R. (2010). Au cœur de la filière aurifère. Jeune Afrique. https://www.jeuneafrique.com/193891/archi ves-thematique/au-c-ur-de-la-fili-re-aurif-re/. Accessed 21 Jul 2020.

Carayol, R. (2020). Goldrausch in der Sahelzone. LE MONDE diplomatique. https://monde-diplomatique. de/artikel/!5653050. Accessed 21 Jul 2020.

Cattaneo, A., \& Robinson, S. (2018). Economic development and the evolution of internal migration: moving in steps, returnees, and gender differences. Background paper prepared for the state of food and agriculture 2018: Migration, agriculture, and rural development. Rome; Washington, D.C., FAO and IFPRI.

Curran, S. R., \& Rivero-Fuentes, E. (2003). Engendering migrant networks: the case of Mexican migration. Demography, 40(2), 289-307. 
De Haas, H. (2005). International migration, remittances and development: Myths and facts. Third World Quarterly. https://doi.org/10.1080/01436590500336757.

De Longueville, F., Zhu, Y., \& Henry, S. (2019). Direct and indirect impacts of environmental factors on migration in Burkina Faso: application of structural equation modelling. Population and Environment, 40(4), 456-479. Springer, Heidelberg.

Doso, S., Jr. (2014). Land degradation and agriculture in the Sahel of Africa: causes, impacts and recommendations. Journal of Agricultural Science and Applications, 3(03), 67-73.

Donato, K. M., Gabaccia, D., Holdaway, J., Manalansan, M., IV., \& Pessar, P. R. (2006). A glass half full? Gender in migration studies. International Migration Review, 40(1), 3-26.

Doss, C. R., Heckert, J., Myers, E., Pereira, A., \& Quisumbing, A. (2020). Gender, rural youth and structural transformation: evidence to inform innovative youth programming. Available at SSRN 3520616.

Ezra, M., \& Kiros, G. (2001). Rural Out-migration in the Drought Prone Areas of Ethiopia: A Multilevel Analysis. International Migration Review, 35(3), 749-771. https://doi.org/10.1111/j.1747-7379. 2001.tb00039.x

FAO. (2019). The State of Food and Agriculture 2019. Moving forward on food loss and waste reduction. Rome. Licence: CC BY-NC-SA 3.0 IGO. http://www.fao.org/3/ca6030en/ca6030en.pdf

Field, C. B., Barros, V. R., Mastrandrea, M. D., Mach, K. J., Abdrabo, M. K., Adger, N., \& Yohe, G. W. (2014). Summary for policymakers. In Climate change 2014: Impacts, adaptation, and vulnerability. Part A: Global and sectoral aspects. Contribution of Working Group II to the Fifth Assessment Report of the Intergovernmental Panel on Climate Change (pp. 1-32). Cambridge University Press.

Gemenne, F., \& Blocher, J. (2017). How can migration serve adaptation to climate change? Challenges to fleshing out a policy ideal. The Geographical Journal, 183(4), 336-347.

Greiner, C., Peth, S. A., \& Sakdapolrak, P. (2015). Deciphering migration in the age of climate change. Towards an understanding of translocal relations in social-ecological systems, TransRe Working Paper No. 2, Department of Geography, University of Bonn, Bonn. https://doi.org/10.13140/2.1. 4402.976

Gong, F., Xu, J., Fujishiro, K., \& Takeuchi, D. T. (2011). A life course perspective on migration and mental health among Asian immigrants: the role of human agency. Social Science \& Medicine, 73(11), 1618-1626. https://doi.org/10.1016/j.socscimed.2011.09.014

Grolle, J. (2015). Historical case studies of famines and migrations in the West African Sahel and their possible relevance now and in the future. Population and Environment, 37, 181-206.

Gray, C. L. (2010). Gender, natural capital, and migration in the southern Ecuadorian Andes. Environment and Planning A, 42(3), 678-696.

Henry, S., Schoumaker, B., \& Beauchemin, C. (2004). The impact of rainfall on the first out-migration: a multi-level event-history analysis in Burkina Faso. Population and Environment, 25(5), 423-460.

Hoang, L. A. (2011). Gender identity and agency in migration decision-making: evidence from Vietnam. Journal of Ethnic and Migration Studies, 37(9), 1441-1457. https://doi.org/10.1080/1369183X. 2011.623618

Hunter, L.M., \& David, E. (2009). Climate change and migration: considering the gender dimensions. IBS, University of Colorado, Boulder, population program working paper POP2009-13.

IPCC. (Ed.). (2021). Climate Change 2021: The physical science basis. Contribution of Working Group I to the Sixth Assessment Report of the Intergovernmental Panel on Climate Change [MassonDelmotte, V., P. Zhai, A. Pirani, S. L. Connors, C. Péan, S. Berger, N. Caud, Y. Chen, L. Goldfarb, M. I. Gomis, M. Huang, K. Leitzell, E. Lonnoy, J. B. R. Matthews, T. K. Maycock, T. Waterfield, O. Yelekçi, R. Yu and B. Zhou (Eds.)]. Cambridge University Press. In Press.

Jaeger, D. A., Dohmen, T., Falk, A., Huffman, D., Sunde, U., \& Bonin, H. (2010). Direct evidence on risk attitudes and migration. Review of Economics and Statistics, 92(3), 684-689.

Jacobson, C., Crevello, S., Chea, C., \& Jarihani, B. (2019). When is migration a maladaptive response to climate change? Regional Environmental Change. https://doi.org/10.1007/s10113-018-1387-6

Kniveton, D. R., Smith, C. D., \& Black, R. (2012). Emerging migration flows in a changing climate in dryland Africa. Nature Climate Change, 2(6), 444-447.

Konseiga, A. (2007). Household migration decisions as survival strategy: the case of Burkina Faso. Journal of African Economies, 16(2), 198-233. https://doi.org/10.1093/jae/ej1025

Kandiyoti, D. (1988). Bargaining with Patriarchy. Gender \& Society, 2(3), 274-290.

Lurie, M. N., Williams, B. G., Zuma, K., Mkaya-Mwamburi, D., Garnett, G. P., Sturm, A. W., Sweat, M. D., et al. (2003). The impact of migration on HIV-1 transmission in South Africa: a study of migrant and non-migrant men and their partners. Sexually Transmitted Diseases, 30(2), 149-156. 
Mank, I., Belesova, K., Bliefernicht, J., Traoré, I., Wilkinson, P., Danquah, I., \& Sauerborn, R. (2021). The Impact of Rainfall Variability on Diets and Undernutrition of Young Children in Rural Burkina Faso. Frontiers in Public Health, 9, https://doi.org/10.3389/fpubh.2021.693281

Massey, D. S., Axinn, W. G., \& Ghimire, D. J. (2010). Environmental change and out-migration: evidence from Nepal. Population and Environment, 32(2-3), 109-136. https://doi.org/10.1007/ s11111-010-0119-8

McLeman, R., \& Smit, B. (2006). Migration as an adaptation to climate change. Climatic Change, 76(1), 31-53.

Menashe-Oren, A., \& Stecklov, G. (2017). Rural/urban population age and sex composition in subSaharan Africa. Population and Development Review, 44(1), 7-35.

Meze-Hausken, E. (2000). Migration caused by climate change: How vulnerable are people in dryland areas? Mitigation and Adaptation Strategies for Climate Change, 5(4), 379-406.

Morokvasic, M. (1984). Women in migration. International Migration Review, 18, 882-1382. PMID: 12280253.

Morrissey, J. (2014). Environmental change and human migration in Sub-Saharan Africa. In: E. Piguet, F. Laczko (Eds), People on the move in a changing climate. Global Migration Issues (vol. 2). Springer, Dordrecht. https://doi.org/10.1007/978-94-007-6985-4_4

Natarajan, N., Brickell, K., \& Parsons, L. (2019). Climate change adaptation and precarity across the rural-urban divide in Cambodia: towards a 'climate precarity' approach. Environment and Planning e: Nature and Space, 2, 899-921. https://doi.org/10.1177/2514848619858155

Nature Climate Change. (2021). Powers of qualitative research. Nature Clinical Practice Endocrinology \& Metabolism, 11, 717. https://doi.org/10.1038/s41558-021-01153-z

Olivier de Sardan, J. -P. (2007). Analyse Rétrospective de la crise alimentaire au Niger en 2005, Document de Travail 45, Département de Résearch, Agence Française de Développement (p. 50).

O'Reilly, K. (2016). Migration theories - A critical overview. In A. Triandafyllidou (Ed.), Routledge Handbook of Immigration and Refugee Studies, (1st ed., pp. 27-28). Routledge.

Pearson, N. T. (2018). Burkina Faso. Routledge Handbook of Environmental Displacement and Migration, 178, 178-187.

Pisarevskaya, A., Levy, N., Scholten, P., \& Jansen, J. (2019). Mapping migration studies: an empirical analysis of the coming of age of a research field. Migration Studies. https://doi.org/10.1093/ migration/mnz031

Porter, J. R., Xie, L., Challinor, A. J., Cochrane, K., Howden, S. M., Iqbal, M. M., et al. (2014). Food security and food production systems. In: C. B. Field, V. R. Barros, D. J. Dokken, K J. Mach, M.D.

Raleigh, C., Jordan, L., \& Salehyan, I. (2008) Assessing the impact of climate change on migration and conflict, Social Development Department, The World Bank, Washington D.C. http:// siteresources.worldbank.org/EXTSOCIALDEVELOPMENT/Resources/SDCCWorkingPaper_ MigrationandConflict.pdf. Accessed 5 Jan 2021.

Sakdapolrak, P., Naruchaikusol, S., Ober, K., Peth, S., Porst, L., Rockenbauch, T., \& Tolo, V. (2016). Migration in a changing climate. Towards a translocal social resilience approach. DIE ERDE - Journal of the Geographical Society of Berlin, 147(2), 81-94. https://doi.org/10.12854/ erde-147-6

Saunders, B., Sim, J., Kingstone, T., et al. (2018). Saturation in qualitative research: Exploring its conceptualization and operationalization. Quality \& Quantity, 52, 1893-1907. https://doi.org/10. 1007/s11135-017-0574-8.

Schwerdtle, P., Bowen, K., \& McMichael, C. (2018). The health impacts of climate-related migration. BMC Medicine, 16(1), 1-7. BioMed Central.

Schwerdtle, P. N., McMichael, C., Mank, I., Sauerborn, R., Danquah, I., \& Bowen, K. (2020). Health and migration in the context of a changing climate: A systematic literature assessment. IOP Publishing.

Stark, O., \& Bloom, D. (1985). The new economics of labor migration. The American Economic Review, 75(2), 173-178. http://www.jstor.org/stable/1805591. Accessed 28 Dec 2020.

Strauss, A., \& Corbin, J. (1967). Discovery of grounded theory: Strategies for qualitative research. New Brunswick, USA and London, UK, USA: Aldine Transaction.

Somé, J. W., \& Jones, A. D. (2018). The influence of crop production and socioeconomic factors on seasonal household dietary diversity in Burkina Faso. PLoS One, 13, 1-16 https://pubmed.ncbi. nlm.nih.gov/29771910/. Accessed 28 Dec 2020. 
Tankari, M. R. (2020). Rainfall variability and farm households' food insecurity in Burkina Faso: nonfarm activities as a coping strategy. Food Security, 12, 567-578 https://link.springer.com/article/10. 1007\%2Fs12571-019-01002-0. Accessed 28 Dec 2020.

Traoré, S., \& Owiyo, T. (2013). Dirty droughts causing loss and damage in Northern Burkina Faso. International Journal of Global Warming, 5(4), 498-513.

UN OCHA. (2020). Burkina Faso Situation Report. https://reports.unocha.org/en/country/burkina-faso/. Accessed 21 Jul 2020.

UNPEI. (2018). Burkina Faso. https://unpei.org/burkina-faso-2/. Accessed 21 Jul 2020.

Vinke, K. (2019). unsettling settlements-cities, migrants, climate change: Rural-urban climate migration as effective adaptation? (Vol. 18). LIT Verlag.

Vinke, K., Bergmann, J., Blocher, J., Updadhyay, H., \& Hoffmann, R. (2020). Migration as adaptation? Migration Studies, Oxford Academic. https://doi.org/10.1093/migration/mnaa029

Warner, K., \& Afifi, T. (2014). Where the rain falls: evidence from 8 countries on how vulnerable households use migration to manage the risk of rainfall variability and food insecurity. Climate and Development, 6(1), 1-17. Taylor \& Francis. https://doi.org/10.1080/17565529.2013.835707

Warner, K., Afifi, T., Henry, K., Rawe, T., Smith, C., \& De Sherbinin, A. (2012). Where the rain falls: climate change, food and livelihood security, and migration. Bonn: Boekenplan.

Weinreb, A., Stecklov, G., \& Arslan, A. (2020). Effects of changes in rainfall and temperature on age- and sex-specific patterns of rural-urban migration in sub-Saharan Africa. Population and Environment, 42, 219-254. https://doi.org/10.1007/s11111-020-00359-1

World Bank. (2016). Migration and Remittances Factbook 2016. World Bank. https://www.knomad.org/ sites/default/files/2017-03/9781464803192_0.pdf. Accessed 21 Jul 2020.

Publisher's Note Springer Nature remains neutral with regard to jurisdictional claims in published maps and institutional affiliations. 